\title{
Learning by research
}

\author{
Saman Wimalasundera \\ Head and Senior Lecturer, Department of Community Medicine, Faculty of Medicine, \\ University of Ruhuna, Galle.
}

Most medical curricula of undergraduate and postgraduate training include research as a component in their teaching process. Research is defined as a systematic investigation and study of materials and sources in order to establish facts and reach new conclusions [1].

Students are expected to carryout research in the form of original work and produce a dissertation. In the undergraduate level it is being done in small scale and in postgraduate level it is a comprehensive work leading to the discovery of new knowledge to the relevant sciences.

What is the purpose of this whole endeavour? When students are trained to do a particular job in Medicine, is it essential to ask them to do research? Why not it be left to the professional researchers and allow the students to engage in more professional training sessions? Answers to these questions can be found by looking at the different learning outcomes achieved through research activities.

Research is an integral part of leaning in Medicine as it provides the student with cognitive, emotional, social and practical experience that helps in developing their knowledge, skills and attitudes. It might be difficult to teach all these qualities by didactic lectures, tutorials, discussions and ward classes. Therefore, research is an essential part in learning Medicine that has to be well structured and supported by the institution and the curriculum.

\section{Active learning in Medicine and research}

The active learning process in Medicine involves student-centered or self-directed learning through their accumulated knowledge and experience, supported by academic members, clinicians and peer interactions [2]. This experience provides a foundation for active learning. Research is active learning which provides the students (undergraduate or postgraduate) an opportunity to make observation, reflect on their experience and analyse ideas they have accumulated through their work and experience. These ideas will eventually lead to the formation of "concepts" or "theories" (assumptions) that can be tested through active experimentation. This will make way to new knowledge and experience. This process starts again and works as a cycle. This cycle of experiential learning is known as Kolb's learning cycle (Figure 1) [3].

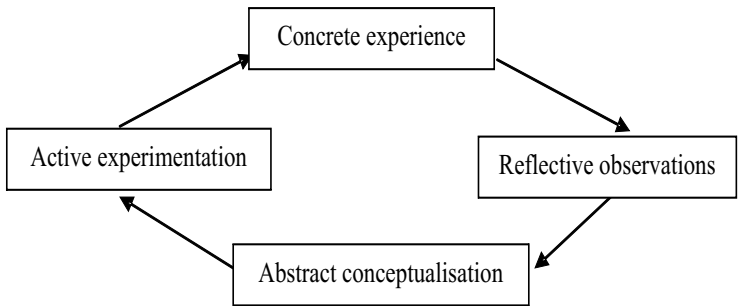

Figure 1 - Kolb's learning cycle [3]

The new experiences generated through different types of learning will reflect on new observations that lead to new concept formations. Concepts have to be subjected to experimentation to prove. This is active learning and learning by research.

\section{Learning through different components of research}

A research project consists of a range of stages, starting from the selection of a topic to writing conclusions. Each one of these stages helps students (researchers) to acquire new knowledge skills and attitudes in their learning development (Table 1). 
Table 1 - Knowledge, skills and attitudes developed through research [4]

\begin{tabular}{|c|c|c|c|c|}
\hline $\begin{array}{l}\text { Research } \\
\text { stage }\end{array}$ & $\begin{array}{c}\text { Experiential } \\
\text { learning process }\end{array}$ & Knowledge gained & Skills gained & $\begin{array}{l}\text { Attitudes } \\
\text { developed }\end{array}$ \\
\hline $\begin{array}{l}\text { Deciding on a } \\
\text { research topic } \\
\text { and objectives }\end{array}$ & $\begin{array}{l}\text { Reflection on past } \\
\text { experience }\end{array}$ & $\begin{array}{l}\text { Developed from } \\
\text { lectures, books, } \\
\text { discussions. } \\
\text { Application of } \\
\text { knowledge to critical } \\
\text { incidence analysis }\end{array}$ & $\begin{array}{l}\text { Handling of } \\
\text { information and } \\
\text { retrieval }\end{array}$ & $\begin{array}{l}\text { Being enquiring } \\
\text { and exploratory }\end{array}$ \\
\hline $\begin{array}{l}\text { Finding the } \\
\text { relevant } \\
\text { information of } \\
\text { the selected } \\
\text { subject } \\
\text { (Literature } \\
\text { search) }\end{array}$ & $\begin{array}{l}\text { Reflection and } \\
\text { conceptualisation }\end{array}$ & $\begin{array}{l}\text { Through knowledge on } \\
\text { core subjects and its } \\
\text { critical analysis to } \\
\text { develop as a research } \\
\& \text { understanding past } \\
\text { research }\end{array}$ & $\begin{array}{l}\text { Literature search, } \\
\text { computing skills } \\
\text { including web search }\end{array}$ & $\begin{array}{l}\text { Being methodical } \\
\text { and being } \\
\text { explorative }\end{array}$ \\
\hline $\begin{array}{l}\text { Designing } \\
\text { methodology }\end{array}$ & Conceptualisation & $\begin{array}{l}\text { Knowledge on proper } \\
\text { methods of how to do } \\
\text { a research. (e.g. } \\
\text { Different } \\
\text { epidemiological study } \\
\text { types) }\end{array}$ & $\begin{array}{l}\text { Designing } \\
\text { questionnaires, data } \\
\text { bases and consent } \\
\text { forms. Sample selection } \\
\text { budgeting and } \\
\text { managing }\end{array}$ & $\begin{array}{l}\text { Being thorough } \\
\text { Reaching targets, } \\
\text { Obtaining } \\
\text { guidance from } \\
\text { supervisors }\end{array}$ \\
\hline Field work & $\begin{array}{l}\text { Active } \\
\text { experimentation }\end{array}$ & $\begin{array}{l}\text { Practical knowledge on } \\
\text { the subject matter, } \\
\text { identify practical } \\
\text { problems }\end{array}$ & $\begin{array}{l}\text { Collecting data, } \\
\text { communication skills, } \\
\text { skills in facing } \\
\text { problems, Leadership }\end{array}$ & $\begin{array}{l}\text { Being careful } \\
\text { about the } \\
\text { application of a } \\
\text { protocol }\end{array}$ \\
\hline Data analysis & $\begin{array}{l}\text { Reflection and } \\
\text { conceptualization }\end{array}$ & $\begin{array}{l}\text { Knowledge and critical } \\
\text { analysis of results to } \\
\text { find new information } \\
\text { and relationships }\end{array}$ & $\begin{array}{l}\text { Data entering skills, use } \\
\text { of statistical packages }\end{array}$ & Being methodical \\
\hline $\begin{array}{l}\text { Writing results } \\
\text { and discussion }\end{array}$ & $\begin{array}{l}\text { Active } \\
\text { experimentation and } \\
\text { reflection }\end{array}$ & $\begin{array}{l}\text { Knowledge on new } \\
\text { findings and results } \\
\text { that will reflect on new } \\
\text { knowledge added to } \\
\text { the main stream }\end{array}$ & $\begin{array}{l}\text { Comparison of results } \\
\text { with others, writing } \\
\text { skills, } \\
\text { interpretation of data, } \\
\text { critical thinking }\end{array}$ & $\begin{array}{l}\text { Being truthful } \\
\text { about results, } \\
\text { appreciation of } \\
\text { limitations, being } \\
\text { reflective }\end{array}$ \\
\hline $\begin{array}{l}\text { Writing } \\
\text { conclusions }\end{array}$ & $\begin{array}{l}\text { Experience and } \\
\text { reflection }\end{array}$ & $\begin{array}{l}\text { Knowledge on what } \\
\text { has been performed } \\
\text { and what has to be } \\
\text { performed in future. }\end{array}$ & $\begin{array}{l}\text { Writing skills } \\
\text { Critical appraisal }\end{array}$ & $\begin{array}{l}\text { Being practical } \\
\text { and innovative }\end{array}$ \\
\hline
\end{tabular}

Concrete knowledge, past experiences and appreciation of challenges will lead to exploring of areas of a research topic. The topic should be of interest to the researcher, stimulating and relevant. This process includes sharing of views with peers, staff and experts in the relevant field. Everybody in this process contributes to this reflective process. The researcher has to be thorough with the relevant core knowledge and should be able to carefully develop the research objectives. Good supervision and well designed curriculum will help students in this process.

Once a topic is selected, students are expected to do a literature review. With the literature review, students get familiarised with the core subjects and learn how to critically evaluate the past research. They become more methodical and 
explorative. A clear view about the subject will reflect in the development of research objectives properly. Stating the objects clearly is a very important point in research development.

Once the objectives are formulated the learning process continues from reflection to conceptualization. The researcher begins to think about the best method of finding the solutions for his research questions or specific objectives.

At this point a researcher has to decide on several issues,

- Design of the study. What epidemiological study type has to be used? Qualitative, Quantitative or both.

- Best method for collecting data.

- Sample size, time frame, budgets and consent process.

By doing this the students' knowledge and experience is applied to conceptualisation process.

Good supervision is mandatory at this point for the students to become more practical and realistic in doing the research.

\section{Learning at experimentation stage}

This is the most exciting part of a research. The field, laboratory, or clinic work integrates the knowledge and skills of the students into a practical application. Researchers learn to get the work organised, train others and supervise them, collect, organise and manage data. They learn the statistical methods of organising data. This will lead to new experiences and help to develop the process of "learning by doing".

As the research continues, the learning process also continues further. The analysis of data and writing up of the dissertation lead to new ideas and views. Therefore, the learning process of reflection and conceptualisation continues. This is an important educative process where students try to compare their findings with the experiences of the others and their pre-conceptions, fallacies and doubts are challenged. This whole process is a unique learning opportunity. This may be the first time students face the challenge of writing and describing their own findings and making recommendations. This experience will help students to develop confidence on their own work. That will serve them to develop leadership qualities.

\section{Institutional role}

Institutions have an important role to play in this whole learning process. The institution should provide the student with the necessary subject knowledge. This has to be embedded in its curriculum. There should be opportunities for the students to develop skills, attitudes, communication skills, and interpersonal relationships through courses, workshops, etc. The institution should provide the right environment for the students to engage with research projects (libraries, computers etc.).

Proper guidance and advice should be given by the supervisors. At the same time, a close observation should be maintained to find whether the ethical guidelines are followed by the students. It is necessary to closely watch the deadlines, targets, progress reports etc. This will help the students to develop their attitudes of being honest and being practical.

In educational settings "learn by doing" is considered a very powerful tool of teaching. "Learn by research" in medical settings has also become a very important tool in both undergraduate and postgraduate levels today.

\section{References}

1. Oxford Advanced English dictionary; Oxford University press.

2. Ludwig Huber, Learning through Research. Improving University Teaching. 25 $5^{\text {th }}$ International Conference Germany, 2000.

3. Kolb D. Experiential Learning, Englewood Cliffs. New Jersey: Prentice Hall, 1984.

4. Daksha Patel. Research and Training programmes. Community Eye Health. Vol. 20: No. 01; 2007. 